\title{
PLANTS
}

\section{THE BUGSEEDS (CORISPERMUM) OF THE PRAIRIE PROVINCES}

\author{
Diana Bizecki Robson
}

The Manitoba Museum, 190 Rupert Avenue, Winnipeg, Manitoba R3B 0N2; E-mail: <drobson@manitobamuseum.ca>

\section{Introduction}

The bugseeds (Corispermum spp.) are a genus of annual plants that are relatively uncommon and favour sandy habitats, such as sand dunes and disturbed sandy soils. The common name is a direct translation of the Greek name (coris = bug, spermum = seed). ${ }^{1}$ Older floras considered several of the bugseed species in North America to be introduced from Europe, namely $C$. hyssopifolium L., C. nitidum Kit., and C. orientale Lam. ${ }^{2-5}$ However, recent research on the genus, including palaeobotanical evidence, suggests that the species found in North America are native and unrelated to European flora, sharing a closer affinity with eastern Asian species. ${ }^{6-8}$ Thus the scientific names that our Corispermum taxa were given previously are now considered invalid; new names that more accurately reflect the uniqueness and American origin are now being used. ${ }^{1}$ In this paper, I will: (1) discuss the taxonomy, habitat, distribution, and ecology of the bugseed genus Corispermum, (2) describe the characteristics of Corispermum species, and (3) present a taxonomic treatment of the genus consisting of a dichotomous key and descriptions of the five species found in Canada. All species but one, namely Hooker's bugseed (C. hookeri), have been found in the United States as well.

In North America, the bugseed genus consists of 11 species, but in the prairie provinces, there are only four: American bugseed (C. americanum (Nutt.) Nutt. var. americanum), Hooker's bugseed ( $C$. hookeri Mosyakin var. hookeri), Pallas bugseed (C. pallasii Steven), and hairy bugseed ( $C$. villosum Rydb.). ${ }^{1}$ Older Canadian floras, such as Budd's Flora ${ }^{2}$ and Flora of Alberta $^{3}$, typically recognize two to four taxa (Table 1). However, the keys in these older floras are not particularly useful for identifying the new species. For example, what was called bugseed (C. hyssopifolium L.) in Budd's Flora could actually be American, Hooker's, or Pallas bugseed. Some of the bugseed plants growing in the Athabasca Sand Dunes in northern Saskatchewan appear to represent a fifth species for the prairies: Alaskan bugseed (C. ochotense Ignatov). ${ }^{8}$ Herbarium specimens of bugseed from that area observed by Dr. Sergei Mosyakin were annotated to Alaskan bugseed from bugseed ( $C$. hyssopifolium) but were noted as being "transitional" to hairy bugseed. Thus it is possible that there are unusual hybrids between Alaskan and hairy bugseed plants in that area. Given that there are several endemic plant species in the Athabasca Sand Dunes, this is certainly a possibility.

Since there have been many changes to bugseed nomenclature, it will be less confusing to simply use the new keys in this article rather than alter the old ones. Contrary to previous keys, the hairiness of the plants is not a reliable character 


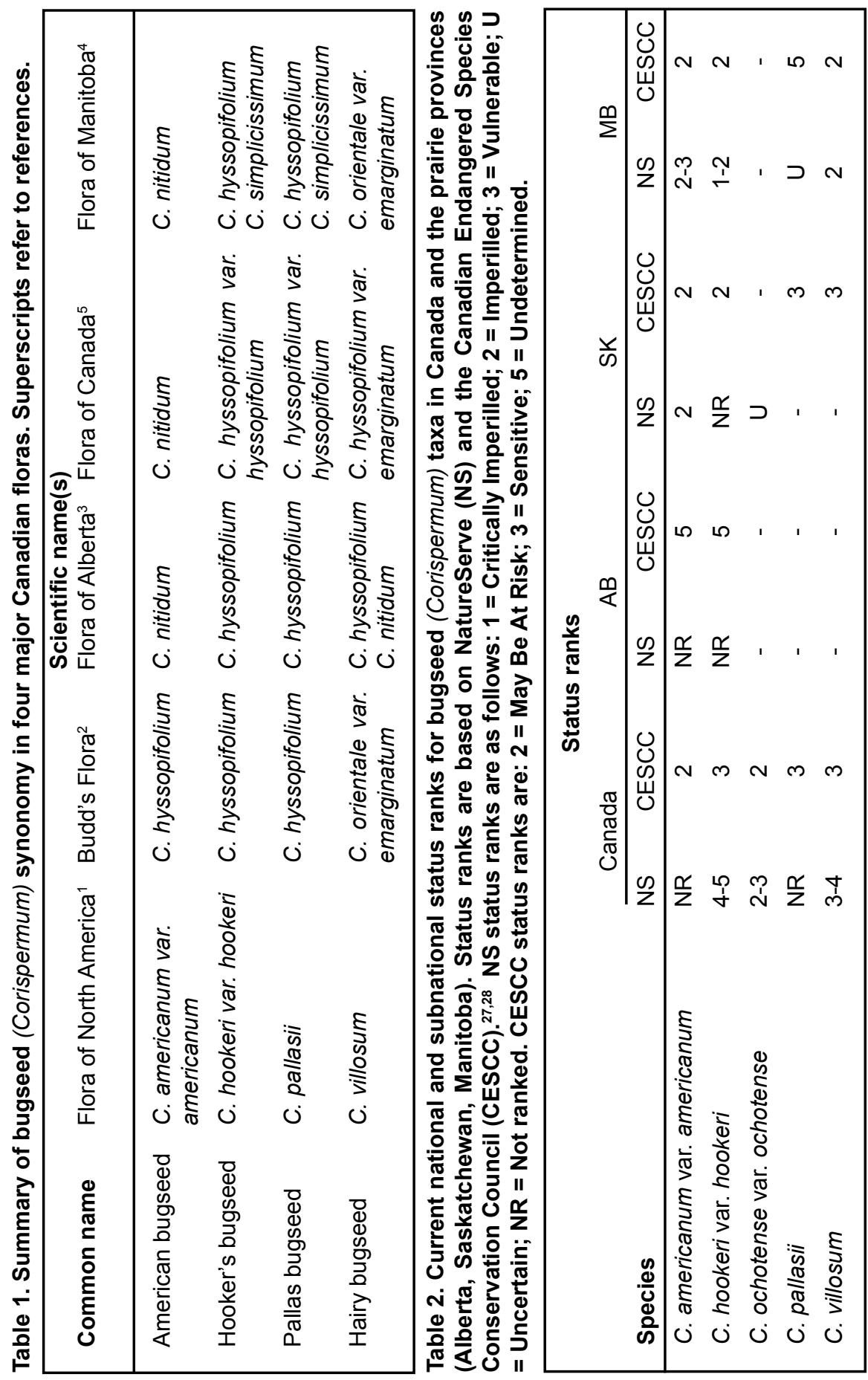




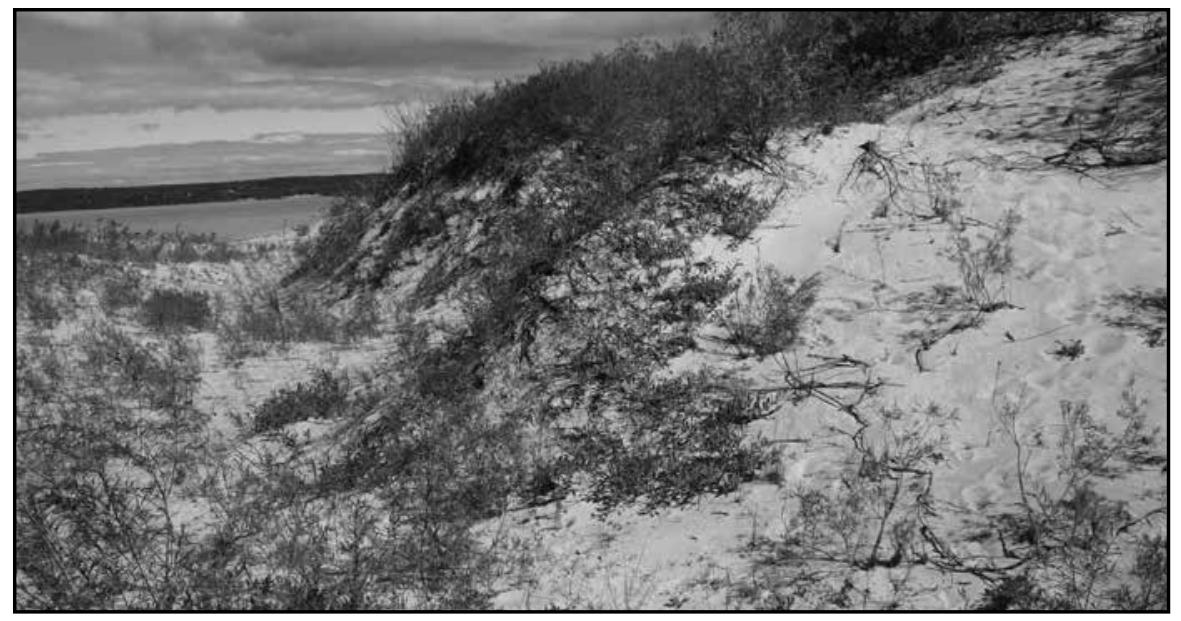

Figure 1. Habitat of hairy bugseed on dunes in Grand Beach Provincial Park, Manitoba. Diana Bizecki Robson.

for distinguishing the new species; rather, the most important characters are the size of the fruits, the presence or absence of a wing, and the density of the inflorescences. ${ }^{8,9}$ For this reason, identification of bugseed species can be difficult when the plant is very young, as mature fruits are generally needed for positive identification.

\section{Habitat and Distribution}

Bugseed plants are typically found on soils high in sand and gravel such as sand dunes (Fig. 1), sandy plains, sandy and gravelly shores of rivers and streams, and sandy waste places. ${ }^{10}$ Several specimens have been found in sandy cultivated fields and along road grades. ${ }^{10}$ Bugseeds are among the few species that are capable of growing on active sand dune complexes. Due to the stabilization of many active sand dune complexes in western Canada, particularly in Manitoba, habitat for these species may be declining. ${ }^{11}$ However, the current dune stabilization trend may reverse itself if climate change results in severe and prolonged droughts on the prairies. ${ }^{12}$
Bugseed species are most commonly found in the Prairie ecozone and less commonly in the Boreal Plain ecozone. ${ }^{13}$ The farthest northern bugseed records in the prairies are from the Athabasca Sand Dunes of Saskatchewan. However, most bugseed plants in Saskatchewan are found in the south, along the sandy banks of the Frenchman, Qu'Appelle, and North and South Saskatchewan Rivers, and in the dunes of the Dundurn, Elbow, Great, Pelican Lake, and Seward Sand Hills. In Alberta, bugseeds have been found along the sandy banks of the Athabasca, Elbow, and Red Deer Rivers, and in the dunes of the Battle River, Beaver Hill, Buffalo Park, Fish Lake, Edson, and Middle Sand Hills. Manitoba plants have been found in the dunes of the Routledge and Brandon Sand Hills, the gravel pits around Birds Hill Provincial Park, and along the sandy shores of Lakes Manitoba and Winnipeg. As the bugseeds lack colourful, attractive flowers and look similar to the several weedy species, it is quite possible that the plants are much more widespread, but under-collected by amateur and professional botanists alike. 


\section{Biology}

All bugseeds are annual, bisexual plants that are wind pollinated. ${ }^{8}$ In Canada, plants begin growing in July, producing ripe seed in late August to early October. The seeds of bugseed may be retained on the parent plant over the winter, which may then be buried by shifting sand. ${ }^{14}$ Seeds that do fall are blown by the wind and accumulate unevenly in small depressions where they are subsequently buried. ${ }^{15}$ Bugseeds form an effective seed bank in the soil due to their innate dormancy, seed longevity, large quantity of seeds produced, and ability to resist decay and dessication. ${ }^{15,16}$ The ability of bugseeds to grow in low-nutrient soils is likely due in part to the relatively large seeds (1.3 to $2.8 \mathrm{mg}$ ), which provide germinating plants with adequate resources for their initial growth. ${ }^{16,17}$ Seeds buried at greater depths tend to have longer hypocotyls. ${ }^{16}$ Bugseeds have low mortality regardless of burial depth, and the seeds are quite long lived, likely more than 20 years. ${ }^{15}$ Once buried seeds are exposed due to dune erosion, the seeds become active and will germinate quickly, as long as adequate moisture is available. ${ }^{15}$ Two to 4 weeks of cold-moist pretreatment were found to be effective in accelerating germination. ${ }^{14}$ Plant size tends to be higher in spots where buried organic matter occurs. ${ }^{14}$ Fluctuations in the population sizes of annual psammophilic (sand-loving) plants are likely related to inter-annual variation in rainfall. ${ }^{18,19}$ Factors that negatively affect plant size and seed production in bugseeds include the degree of stabilization of the sand and the level of herbivory. Both plant size and reproductive allocation is lower in highly mobile habitats, and when herbivory is high. ${ }^{20,21}$

\section{Economic Impact}

Bugseeds are in the goosefoot family, which contains both economically valuable edible species, like spinach (Spinacia oleracea L.), quinoa (Chenopodium quinoa Willd.), and beet and Swiss chard (Beta vulgaris L.), as well as noxious weeds, such as Russian pigweed (Axyris amaranthoides L.), summer cypress (Kochia scoparia (L.) Schrad.), and Russian thistle (Salsola tragus L.). ${ }^{22}$ Some species are considered to be both; for example, lamb's-quarters (Chenopodium album L.), considered a troublesome weed in croplands, is also a nutritious potherb. ${ }^{22}$ In China, one species of bugseed (C. declinatum Stephan ex. Iljin) is used to flavour gin. ${ }^{23}$ There is also evidence that the Hopi Indians of Arizona consumed bugseed seeds, as charred remains were found in ancient hearths along with maize (Zea mays L.) and other wild seeds. ${ }^{24}$ The potential of bugseeds to become crop plants has not been explored. Despite the annual habit and tolerance of mild disturbance that bugseeds possess, they have not become troublesome weeds in croplands, possibly because they are susceptible to dampingoff fungi when grown in finer soils high in organic matter; ${ }^{14}$ this tendency may limit the agricultural potential of wild bugseeds in all but sandy soils.

In northern China where desertification is severe, bugseeds are noted to play an important role in stabilizing degraded sandy lands. ${ }^{21,25}$ This is because bugseeds form an effective seed bank in the soil due to their innate dormancy, seed longevity, large quantity of seeds produced, and ability to resist decay and desiccation. ${ }^{16,23}$ North American bugseeds could potentially be used for ecological reclamation of reactivated dunes and/or sandy areas disturbed during sand and gravel mining, road construction, or oil and gas exploration. ${ }^{26}$ Unfortunately, seeds of this species are not typically available from seed suppliers.

\section{Status of the Bugseeds}

The current status ranks of bugseeds 
according to NatureServe ${ }^{27}$ and the Canadian Endangered Species Conservation Council ${ }^{28}$ are noted in Table 2. However, these ranks are somewhat inaccurate because new information on the distribution and abundance of bugseed species in Canada based on a recent review of herbarium specimens has not been incorporated yet. ${ }^{10}$

The rarity of some bugseed species and drastic changes in the taxonomy makes collection and identification of plants in this genus challenging. They are typically overlooked and seldom collected or photographed due to their lack of large, colourful flowers. Additional research on the current distribution and abundance of bugseed plants is needed to more accurately rank the bugseed species in the prairies. Any specimens observed are worth collecting and donating to herbaria to better determine the distribution and frequency of these species. Mature specimens with well-developed fruits are the easiest to identify; immature specimens may be unidentifiable even by an expert. In general, the best time to collect bugseed specimens is from August to October.

\section{Description of Corispermum ${ }^{1,8,9}$}

This genus contains annual herbs, most of which possess branched, almost star-like hairs. The stems are erect or ascending, branched, and unarmed. The leaves are alternate and sessile on the stem, linear to linear-lanceolate in shape, with entire margins, a truncate base, and an acute apex. The inflorescences consist of terminal spikes with ovate, lanceolate, or linear leafy bracts. The flowers are solitary in the axils of the bracts and imperfect, with one scale-like sepal. The flower consists of one to three, rarely five, stamens and a superior ovary with two stigmas and styles. The styles persist to form a distinct "beak" at the apex of the fruit. The fruits are lens-shaped, ovate, obovate, elliptic, or orbiculate in shape, usually broadest beyond the middle, somewhat convex on one side and concave on the other, and often possessing a wing around the margin that connects to the beak (Fig. 2). The apices of the fruits are acute, glabrous and shiny or maculate and verrucose. The pericarp adheres strongly to the seed, but in C. pallasii they may flake off, forming small whitish bladders. To differentiate bugseeds from Russian thistle, the leaf tips must be examined closely: Russian thistle has a spine on the very tip of the leaf, whereas bugseeds merely have an acute tip. Another similar plant, summer cypress, has three to five sepals and wingless egg-shaped seeds. To aid in identification, a key to the taxa as well as photographs of Agriculture \& Agri-Food Canada Vascular Plant Herbarium (DAO) specimens are provided. Note that this key can be used to identify any bugseed taxa found in all of Canada, not just the prairies.

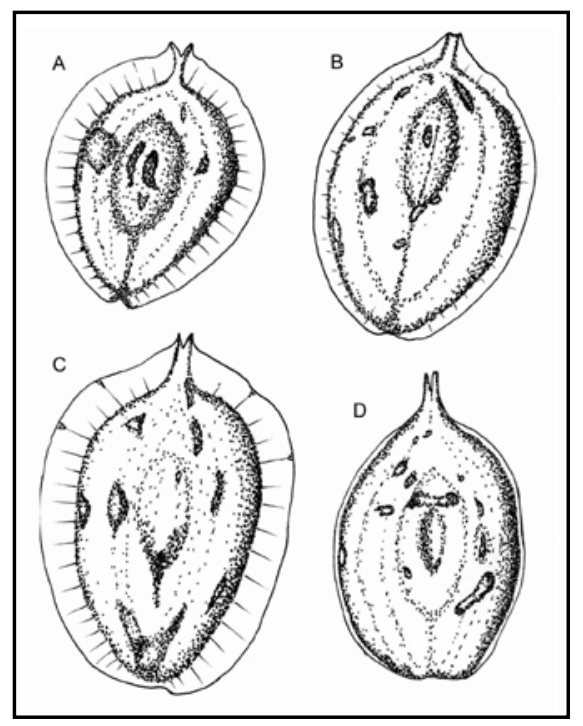

Figure 2. Illustrations of American bugseed (A), Hooker's bugseed (B), Pallas bugseed (C) and hairy bugseed (D) seeds. Drawn to scale. Line drawings by Diana Bizecki Robson 
Identification Key to the Corispermum Taxa of the Prairies ${ }^{1,8,9}$

1a. Fruits $1.8-3.2 \mathrm{~mm}$ long, wingless, or with a barely visible narrow wing less than $0.1 \mathrm{~mm}$ wide; beak protruding well past the edge of the wing C. villosum

1b. Fruits $2.3-5.0 \mathrm{~mm}$, wings $0.1-0.5$ $\mathrm{mm}$ wide, if almost wingless, then fruits $3.5-5.2 \mathrm{~mm}$ wide; beak barely protruding past the edge of the wing ...... 2

2a. Plants 5-15 $(-20) \mathrm{cm}$; fruits reddish brown or olive green tinged with red, typically developed in axils of middle and lower leaves; arctic or subarctic C. ochotense

2b. Plants $5-60 \mathrm{~cm}$; fruits yellowish, brown, or olive, developed only in axils of inflorescence bracts; temperate regions 3

3a. Inflorescences at maturity narrowly linear or linear, lax, usually interrupted from base to apex; leaf blades narrowly linear

C. americanum

3b. Inflorescences at maturity linearclavate to ovate, rather dense or at least condensed towards apex; leaf blades narrowly lanceolate, linear-lanceolate, or linear......... 4

4a. Fruits wingless or wings $0.1-0.2$ $\mathrm{mm}$ wide; fruit body usually strongly convex abaxially, plane to strongly concave adaxially C. hookeri

4b. Fruits with wings $0.2-0.5 \mathrm{~mm}$ wide, slightly convex abaxially, plane to slightly concave adaxially.....

C. pallasii

\section{Descriptions of Bugseed Species ${ }^{1,8,9}$}

The plants are arranged alphabetically by their scientific names. After each name is a list of the synonyms (i.e. former names) for that species. The flowering period is noted in the descriptions, but it can vary considerably depending on the geographic location and weather conditions.

\section{Corispermum americanum (Nutt.) Nutt. var. americanum - American bugseed}

[C. hyssopifolium L. var. americanum Nutt., C. $h$. L. var. rubricaule Hook., C. imbricatum A. Nels., C. nitidum auct. non Kit. ex Schultes, C. marginale Rydb., C. orientale auct. p.p. non Lam., C. simplicissimum Lun.]

An herbaceous annual branched from or beyond the base, $10-35(-50)$ $\mathrm{cm}$ tall. Stems sparsely covered with forking or star-like hairs, often becoming glabrous with age. Leaf blades linear or narrowly linear, plane or folded, $1.3-3.5(-4) \mathrm{cm}$ long and $0.1-0.3 \mathrm{~cm}$ wide. Inflorescences usually lax and interrupted, rarely condensed distally, linear, narrowly linear, or occasionally narrowly club-shaped. Bracts ovatelanceolate, lanceolate, linear-lanceolate, or occasionally proximal ones almost linear, much longer than distal, 0.5$2(-3.5) \mathrm{cm}$ long and $(0.2-) 0.3-0.7 \mathrm{~cm}$ wide. Fruits yellowish brown, greenish brown, light brown or brown, often with reddish brown spots and whitish warts, slightly convex on one side and plane or slightly concave on the other, obovate or obovate-elliptic, shiny or dull, (2.3)2.5-3.5 mm long and $2-3.5 \mathrm{~mm}$ wide; wing translucent, thin, $0.2-0.3 \mathrm{~mm}$ wide, margins entire or rarely irregularly toothed, apex broadly triangular, less commonly truncate or rounded. July-September. Native and uncommon in sand dunes, hills and plains, and sandy disturbed areas in British Columbia, Alberta, Saskatchewan, Manitoba, Ontario, and Quebec (Fig. 3, see inside front cover, top).

\section{Corispermum hookeri Mosyakin - Hooker's bugseed}

[C. hyssopifolium auct. p.p. non L., C. orientale Lam. var. emarginatum auct. p.p. 
non (Rydb.) Macbr.]

An herbaceous annual plant often branched from the base, $10-40(-60) \mathrm{cm}$ tall. Stems sparsely covered with forking and almost star-like hairs. Leaf blade narrowly lanceolate or linear lanceolate, plane, 2-5 cm long and (0.1-)0.2-0.5($0.6) \mathrm{cm}$ wide. Inflorescences usually dense, ovoid, ovate-cylindric, clubshaped, rarely interrupted near base in outline. Bracts ovate or ovate-lanceolate, strongly overlapping, $0.5-1.5(-2) \mathrm{cm}$ long and $0.3-1 \mathrm{~cm}$ wide. Fruits usually deep olive green, brown, or rarely almost black, usually without spots or warts, strongly convex on one side and prominently concave to almost plane on the other, oblong-obovate to obovate, (3.2-)3.5$4.5(-5) \mathrm{mm}$ long and $2.2-3.3(-3.5) \mathrm{mm}$ wide; wing, if present semi translucent to $0.2 \mathrm{~mm}$ wide, margins entire, apex rounded, or indistinctly triangular. JulySeptember. Native and uncommon in sand dunes, hills, and plains, less common in sandy disturbed areas in British Columbia, Alberta, Saskatchewan, Manitoba, Ontario, Quebec, and the Northwest Territories (Fig. 4, see inside front cover, top). There are two varieties in Canada, but $C$. $h$. var. pseudodeclinatum has so far only been found in southern British Columbia. The following key can be used to differentiate the two varieties:

1a. Inflorescences dense throughout, rarely interrupted; fruits oblongovate to obovate

C. h. var. hookeri

1b. Inflorescences dense only at apex, interrupted; fruits elongate to oblongobovate, two times as long as broad

C. $h$. var. pseudodeclinatum

\section{Corispermum ochotense Ignatov} - Alaskan bugseed

An herbaceous annual usually branched from the base or nearly so, $5-15(-20) \mathrm{cm}$ tall. Stems sparsely covered with forking or star-like hairs, becoming glabrous with age. Leaf blades linear-oblanceolate, or linear, plane, $1-3.5 \mathrm{~cm}$ long and $0.1-0.3 \mathrm{~cm}$ wide abruptly contracted into a mucronulate apex. Inflorescences compact and dense, short-clavate, almost ovoid, or linear and with leaf-like bracts. Bracts ovate-lanceolate, lanceolate, or linear-lanceolate (0.5-)1-1.5(-3) cm long and $(0.1-) 0.2-0.5 \mathrm{~cm}$ wide. Fruits beet red, reddish brown, dark brown, or deep olive green and typically tinged with red, usually without dark spots or whitish warts, strongly convex abaxially, plane or slightly convex adaxially, obovate-elliptic or almost obovate, broadest near the middle dull, (2.5-)2.8-4 mm long and 1.8-2.7 $\mathrm{mm}$ wide; wing (0.1-)0.2-0.3 mm wide, margins entire, apex broadly triangular or almost rounded, thick and translucent only at margins. July-September. Native and uncommon in sand dunes, sandy and gravely shores, and disturbed sandy soils in the arctic and subarctic of the Northwest Territories and the Yukon, and possibly northern Saskatchewan, although no definitive specimens have been collected yet. There are two varieties of this species in Canada, but the specimens found in Saskatchewan appeared to be variety ochotense. The two varieties can be distinguished using the following key: ${ }^{8}$

3a. Fruits (2.5)2.8-3.2 mm long $\times$ 1.8-2.2 $\mathrm{mm}$ wide.

C.o. var. ochotense

3b. Fruits $3.2-4 \mathrm{~mm}$ long $\times 2.2-2.7 \mathrm{~mm}$ wide. C.o. var. alaskanum

\section{Corispermum pallasii Steven-Pallas bugseed}

[C. hyssopifolium L. var. leptopterum Asch., C. leptopterum (Asch.) Iljin, C. sibiricum Iljin ssp. baicalense Iljin]

An herbaceous annual branched from near the base, $10-45(-60) \mathrm{cm}$ tall. Stems sparsely covered with forking or almost star-like hairs, becoming glabrous with age. Leaf blades linear-lanceolate, linear or occasionally narrowly linear, plane, 
$1.5-4 \mathrm{~cm}$ long and (0.1-)0.2-0.4(-0.5) $\mathrm{cm}$ wide. Inflorescences compact and dense, rarely lax and interrupted, clubshaped or almost ovate in outline. Bracts ovate or ovate lanceolate, (0.5-)1-3 cm long and $0.4-0.8 \mathrm{~cm}$ wide. Fruits light to dark brown or deep olive green, often with reddish brown spots and whitish warts, convex on one side and plane or slightly concave on the other, obovate or obovate-elliptic, (3.2-)3.5-4.5(-4.7) $\mathrm{mm}$ long and (2-)2.4-5 mm wide; wing translucent only at the margin, thick, $0.2-0.4(-0.5) \mathrm{mm}$ wide, margins entire or irregularly toothed, apex broadly triangular, rarely rounded or indistinctly emarginated. July-September. Native and uncommon in sand hills and plains, and disturbed sandy/gravelly soils in British Columbia, Alberta, Saskatchewan, Manitoba, Ontario, and Quebec.

\section{Corispermum villosum Rydb. - Hairy bugseed}

[C. emarginatum Rydb., C. hyssopifolium L. var. emarginatum (Rydb.) Boiv., C. orientale Lam. var. emarginatum (Rydb.) Macbr.]

An herbaceous annual usually branched from the base or nearly so, (5-)10-30($35) \mathrm{cm}$ tall. Stems densely or sparsely covered with forking or star-like hairs, occasionally becoming glabrous with age. Leaf blade linear-oblanceolate, linear or rarely narrowly linear, plane, (1-)1.5-3.5 cm long and (0.1-)0.2-0.3 $\mathrm{cm}$ wide. Inflorescences compact and dense, condensed in distal half, usually club-shaped to somewhat linear in outline. Bracts ovate, ovate lanceolate, or narrowly ovate-lanceolate $0.5-1.5(-2.5) \mathrm{cm}$ long and (0.3-) $0.5-1 \mathrm{~cm}$ wide. Fruits yellowish brown, or light to dark brown, usually with reddish brown spots and occasionally whitish warts, strongly convex on one side, plane or slightly convex on the other, elliptic or obovate-elliptic, dull, beak protruding above the seed, 1.8-3(-3.2) $\mathrm{mm}$ long and $1.5-2 \mathrm{~mm}$ wide; wing absent or to $0.1 \mathrm{~mm}$ wide, margins entire, apex triangular. July-September. Native and uncommon in sand dunes, hills and plains, and disturbed sandy soils in British Columbia, Alberta, Saskatchewan, Manitoba, Ontario, Quebec, and Northwest Territories (Fig. 5, see inside front cover, top).

\section{Acknowledgements}

Financial support for this research was received from The Manitoba Museum Foundation Inc. Dr. Vernon Harms graciously reviewed an earlier version of this manuscript. Collections at the following herbaria were examined: University of British Columbia (UBC), Royal British Columbia Museum (V), University of Alberta (ALTA), University of Calgary (UAC), Royal Alberta Museum (RAB), University of Regina (USAS), University of Saskatchewan (SASK), University of Manitoba (WIN), The Manitoba Museum (MMMN), Royal Ontario Museum (ROM), University of Guelph (OAC), University of Western Ontario (UWO), University of Waterloo (WAT), University of Toronto (TRTE), Agriculture \& Agri-Food Canada Vascular Plant Herbarium (DAO), Canadian Museum of Nature (CAN), University of Montreal (MT), McGill University (MTMG), University of Laval (QFA), and the Government of Quebec (QUE).

1. Welsh SL, Crompton CW, Clemants SE (2003) Chenopodiaceae. In: Flora of North America Editorial Committee (eds) Flora of North America, Vol 4. Oxford University Press, New York, NY, p 258-404.

2. Looman J, Best KF (1979) Budd's Flora of the Canadian Prairie Provinces. Canadian Government Publishing Centre, Supply and Services Canada, Hull, QC.

3. Moss EH (1983) Flora of Alberta ( $2^{\text {nd }}$ edn by J.G. Packer). University of Toronto Press, Toronto, ON.

4. Scoggan HJ (1956) Flora of Manitoba. National Museum of Canada, Ottawa, ON.

5. Scoggan HJ (1978) The Flora of Canada. National Museum of Canada, Ottawa, ON. 
6. Betancourt JL, Long A, Donahue DJ, Jull AJ, Zabel TH (1984) Pre-Columbian age for North American Corispermum L (Chenopodiaceae) confirmed by accelerator radiocarbon dating. Nature 311:653655.

7. Matthews JV, Schweger CE, Hughes OL (1990) Plant and insect fossils from the May Indian village section (central Yukon): new data on middle Wisconsinan environments and glaciation. Geographie Physique et Quaternaire 44:15-26.

8. Mosyakin SL (1995) New taxa of Corispermum L. (Chenopodiaceae), with preliminary comments on the taxonomy of the genus in North America. Novon 5:340-353.

9. Sukhorukov AP (2007) Fruit anatomy and its taxonomic significance in Corispermum (Corispermoideae, Chenopodiaceae). Willdenowia 37:63-87.

10. Robson DB (In press)An analysis of the distribution, ecology and status of bugseeds (Corispermum) in Canada. Canadian Field Naturalist.

11. Hugenholtz $\mathrm{CH}$, Wolfe SA (2005) Recent stabilization of active sand dunes on the Canadian prairie and relation to recent climate variations. Geomorphology 68:131-147.

12. Wolfe S, Thorpe J (2005) Shifting sands: climate change impacts on sand hills in the Canadian prairie and implications for land use management. Prairie Forum 30:123-142.

13. Marshall IB, Schut PH (1999)A national ecological framework for Canada. Ecosystems Science Directorate, Environment Canada and Research Branch, Agriculture and Agri-food Canada, Ottawa, ON.

14. Van Asdall W, Olmstead CE (1963) Corispermum hyssopifolium on the Lake Michigan dunes - its community and physiological ecology. Botanical Gazette 124:155-172.

15. Zhang J, Maun MA (1994) Potential for seed bank formation in seven Great Lakes sand dune species. American Journal of Botany 81:387-394.

16. Maun MA, Lapierre J (1986) Effects of burial by sand on seed germination and seedling emergence of four dune species. American Journal of Botany 73:450-455.

17. Stevens OA (1932) The number and weight of seeds produced by weeds. American Journal of Botany 19:784-794.
18. Li FR, Zhao LY, Zhao XY, Zhang TH, Li G (2005) The relative importance of pre- and post-germination determinants for recruitment of an annual plant community on moving sandy land. Annals of Botany 96:1215-1223.

19. Robson DB (2006) A conservation evaluation of smooth goosefoot, Chenopodium subglabrum (Chenopodiaceae), in Canada. Canadian Field Naturalist 120:335-341.

20. Gedge KE, Maun MA (1992) Effects of simulated herbivory on growth and reproduction of two beach annuals Cakile edentula and Corispermum hyssopifolium. Canadian Journal of Botany 70:24672475 .

21. He $Y H$, Zhao HA, Liu XP, Zhao $X Y$, Zhang TH, Drake S (2009) Reproductive allocation of Corispermum elongatum in two typical sandy habitats. Pakistan Journal of Botany 41:1685-1694.

22. Robson DB (2008) The prairie goosefoots. Blue Jay 66(2):82-95.

23. Zhu G, Mosyakin SL, Clemants SE (2003) Chenopodiaceae. In: Wu Z, Raven PH (eds) Flora of China, Vol 5. Science Press, Beijing \& Missouri Botanical Garden Press, St. Louis, MO, p 351-414.

24. Adams C (2004) Homol'ovi IV: The First Village. Arizona State Museum Occasional Electronic Papers No. 1, Arizona State Museum, University of Arizona, Tuscon, AZ

25. Liu M, Jiang G, Yu S, Li Y, Li G (2009) The role of soil seed banks in natural restoration of the degraded Hunshandak Sandlands, Northern China. Restoration Ecology 17:127-136.

26. Kelso T, Bower N, Halteman P, Tenney K, Weaver $S$ (2007) Dune communities of SE Colorado: patterns of rarity, disjunction and succession. In: Barlow-Irick $\mathrm{P}$, Anderson J, McDonald C (eds) Southwestern Rare and Endangered Plants: Proceedings of the $4^{\text {th }}$ conference. U.S. Department of Agriculture, Forest Service, Rocky Mountain Research Station, Fort Collins, CO, p 39-48.

27. NatureServe (2010) NatureServe Explorer: an online encyclopedia of life [web application]. Version 6.0. NatureServe, Arlington, VA. Available at <http:// www.natureserve.org/explorer>.

28. Canadian Endangered Species Conservation Council (CESCC) (2006) Wild Species 2005: the general status of species in Canada. Available at: <http://www.wildspecies.ca/wildspecies2005/ GS2005_site_e.pdf. 